\title{
SOURCE CHARACTERISTICS OF BRAZILIAN KIMBERLITES
}

Bizzi, L.A.', Pimentel, M. ${ }^{2}$

1. SOPEMI Pesquisa e Exploração de Minérios S.A. SIA Trecho 2, lote 1591. Brasilia, DF, Brazil.

2. Instituto de Geociências, Universidade de Brasilia, 70910-900. Brasilia, DF, Brazil.

The source characteristics of Group I-type kimberlites $\left({ }^{143} \mathrm{Nd} /{ }^{144} \mathrm{Nd}\right.$ averaging 0.51270 and ${ }^{87} \mathrm{Sr} /{ }^{86} \mathrm{Sr}$ averaging 0.70440) in the Paranatinga/Batovi kimberlite Province in eastern Brazil contrast markedly with the Enriched Mantle source-type kimberlites now recognized in the Jaibaras $\left({ }^{143} \mathrm{Nd} /{ }^{144} \mathrm{Nd}\right.$ averaging 0.51241 and ${ }^{87} \mathrm{Sr}{ }^{86} \mathrm{Sr}$ averaging 0.70532$)$ and Moana Tinguins $\left({ }^{1+3} \mathrm{Nd} /{ }^{144} \mathrm{Nd}\right.$ averaging 0.51251 and ${ }^{87} \mathrm{Sr} /{ }^{86} \mathrm{Sr}$ averaging 0.70639$)$ Kimberlite Provinces in northern Brazil and with those reported for the Coromandel kimberlite Province $\left({ }^{143} \mathrm{Nd} /{ }^{144} \mathrm{Nd}\right.$ averaging 0.51225 and ${ }^{87} \mathrm{Sr}{ }^{86} \mathrm{Sr}$ averaging 0.70525 for kimberlites s.s; Bizzi et al., 1995) in central Brazil.

Peridotite nodules from the Jaibaras kimberlites yield enriched isotope signatures $\left({ }^{143} \mathrm{Nd} /{ }^{144} \mathrm{Nd}\right.$ averaging 0.51242 and ${ }^{87} \mathrm{Sr}{ }^{86} \mathrm{Sr}$ averaging 0.70521 ) which are similar to those of the kimberlites in which they have been incorporated. Such an observation is consistent with the overall source characteristics of the kimberlites and implies that, as much as the isotopically similar high-Ti basalts of the Maranhao Basin, such kimberlites either undergone extensive interaction with or were derived from LREE enriched sources located in the local mantle lithosphere.

The enriched source type kimberlites in Brazil appear to be restricted to areas affected by NeoProterozoic tectono-thermal overprint and their radiogenic isotopes are consistent with a sequence of events in which the mantle lithosphere was enriched in incompatible elements as a result of that [Braziliano] event. The similarity between the isotope characteristics of the mantle source of these kimberlites and those of the mantle source of CFB's and OIB's is tentatively ascribed to large scale mantle heterogeneities and to processes by which Brazilian continental lithosphere became first delaminated and then contaminated bits of South Atlantic asthenosphere from which hot spot islands have been erupting.

The isotope characteristics of the Paranatinga/Batovi Kimberlites have been used as an end member in the simulation of the mixing process proposed for the Coromandel area by Bizzi et al (1995) on the basis of both radiogenic isotopes and PGE. It was found that the compositions of the Coromandel Kimberlites and related rocks can be satisfactorily duplicated by the addition of a small amount of Paranatinga/Batovi component to the average [EMI-like] mantle lithosphere component identified in Coromandel. Interestingly enough, the isotope signatures of the Walvis Ridge basalts (Richardson et al., 1982) could also be simulated using such end members. Such an exercise illustrates the possibility of tracking some of the kimberlites emplaced along the 125AZ lineament (Bardet. 1977) and the Walvis Ridge basalts to the influence of a DUPAL-type mantle plume across the South American continent.

Bardet, M.G., 1977. Geologie du diamant. Troisieme parte: gisements de diamants D'Asie, D'Amerique, D'Europe et D'Australasie. Bureau Recherches Geologiques et Minieres, Memoire 83, 169p. 
Bizzi, L.A., Wit, M.J., Smith, C.B., Macdonald, I. \& Armstrong, R.A.; 1995. Heterogeneous enriched mantle materials and Dupal-Tipe magmatism along the SW margin of the São Francisco Craton, Brazil. J. Geodyn. 20: 469-491.

Richardson S.H., Erlank A.J., Duncan A.R. and Reid D.L. (1982). Correlated Nd, $\mathrm{Sr}$ and $\mathrm{Pb}$ isotope variation in Walvis Ridge Basalts and implications for the resolution of their mantle source. Earth and Planetary Science Letters 59, 327-342. 